\title{
Pemberian Pakan Secara Adlibitum dan Jadwal Persentase Pakan Siang dan Malam Terhadap Bobot Akhir, Karkas, Lemak Abdomen serta Ketebalan Usus pada Ayam Petelur Jantan
}

\author{
The Feed Given Adlibitum and Schedule Percentage of Day and Night Feed Against the \\ Final Body Weight, Carcass, Abdomen Fat, and Intestinal Thickness in Male Laying Hens
}

\author{
T. D. Nova*, Y. Heryandi, dan W. S. Br. Surbakti \\ Program Studi Peternakan, Fakultas Peternakan, Universitas Andalas, Padang \\ *E-mail: tertiaunand@ymail.cm \\ (Diterima: 29 Juni 2019; Disetujui: 14 Agustus 2019)
}

\begin{abstract}
ABSTRAK
Penelitian ini bertujuan untuk mengetahui pengaruh pemberian pakan secara adlibitum pembatasan persentase jumlah pakan pada jadwal waktu makan yang efesien terhadap bobot akhir, karkas, persentase karkas, persentase lemak abdomen, dan ketebalan usus halus pada ayam petelur jantan. Pada penelitian ini menggunakan 125 ekor anaka ayam (DOC) petelur jantan yang ditempatkan pada 25 unit kandang box. Sejumlah 5 ekor ayam petelur jantan dijadikan unit perlakuan. Penelitian ini dilakukan dengan metode Rancangan Acak Lengkap (RAL) selama 10 minggu dengan jadwal waktu persentase makan pagi-siang dan sore-malam yang sama dan persentase jumlah persentase pakan yang berbeda. Pada perlakuan T0: persentase pakan secara adlibitum, T1 : 30\% pagi-siang dan 70\% sore-malam, T2: $40 \%$ pagi-siang dan 60\% sore-malam, T3 : 50\% pagi-siang dan 50\% sore-malam, dan T4: $60 \%$ pagi-siang dan $40 \%$ soremalam. Variabel yang diamati yaitu bobot akhir (g/ekor), karkas (g/ekor), persentase karkas, persentase lemak abdomen, dan ketebalan usus halus $(\mathrm{g} / \mathrm{cm})$. Hasil analisis penelitian ini menunjukkan bahwa pengaruh ad libitum (tanpa batas) terhadap persentae karkas, persentase lemak abdomen, dan ketebalan usus halus, berpengaruh sangat nyata $(\mathrm{P}<0,01)$ sedangkan pembatasan persentase pakan terhadap bobot akhir dan karkas.persentase pakan pada jadwal waktu persentase makan memberikan pengaruh tidak nyata $(\mathrm{P}>0,05)$ terhadap bobot akhir, karkas, Hasil penelitian menunjukkan angka bobot akhir T0 $(638,80 \mathrm{~g} /$ ekor), bobot akhir persentase pakan (562,08-578,88 g/ekor), Karkas T0 (401,20 g/ekor) karkas persentase persentase pakan (337,80-356,40 g/ekor), persentase karkas (60,10-62,76\%), persentase lemak abdomen $(0,72-1,16 \%)$, dan ketebalan usus halus $(0,175-0,196 \mathrm{~g} / \mathrm{cm})$. Kesimpulan penelitian ini bahwa persentase jumlah persentase pakan pada jadwal waktu persentase makan menghasilkan bobot akhir, karkas, persentase karkas, persentase lemak abdomen, dan ketebalan usus halus yang sama. Persentase pakan adlibitum (tanpa batas) setiap hari menghasilkan bobot akhir dan karkas yang tertinggi yaitu masing- masing bobot akhir $638,80 \mathrm{~g} /$ ekor dan bobot karkas 401,20 g/ekor.
\end{abstract}

Kata kunci: ayam petelur jantan, bobot akhir, karkas, lemak abdomen, pembatasan pakan, usus halus

\section{ABSTRACT}

This study aims to determine the effect of feeding adlibitum restriction on the percentage of feed on an efficient meal schedule to the final weight, carcass, carcass percentage, percentage of abdominal fat, and small intestine thickness in male laying hens. In this study, 125 male laying hens (DOC) were placed in 25 units of box cages. The total of 5 male laying hens used as units treatment. This research was conducted with a completely randomized design (CRD) method for 10 weeks with a time schedule of the same percentage of breakfast-lunch and evening and the percentage of different percentage of feed. In the treatment of T0: the percentage of feed adlibitum, T1: 30\% in the morning and 70\% in the afternoon, T2: $40 \%$ in the afternoon and $60 \%$ in the afternoon, T3: $50 \%$ in the morning and $50 \%$ in the afternoon, and T4: $60 \%$ in the afternoon and $40 \%$ in the afternoon. The observed variables were final weight ( $\mathrm{g} / \mathrm{head}$ ), carcass ( $\mathrm{g} / \mathrm{head}$ ), percentage of carcass, percentage of abdominal fat, and small intestine thickness ( $\mathrm{g} /$ 
$\mathrm{cm}$ ). The results of the analysis of this study indicate that the effect of ad libitum (no limit) on the percentage of carcass, percentage of abdominal fat, and thickness of the small intestine, has a very significant effect $(P<0.01)$ while limiting the percentage of feed on the final weight and carcass. When the percentage of food gives no significant effect $(P>0.05)$ on the final weight, carcass, the results of the study show the final weight value of T0 (638.80 g / head), final weight percentage of feed (562.08-578.88 $\mathrm{g} / \mathrm{head}$ ), T0 carcass $(401.20 \mathrm{~g} / \mathrm{head})$ percentage of feed carcass percentage (337.80-356.40 g/ head), carcass percentage (60.10-62.76\%), abdominal fat percentage (0.72-1.16\%), and the thickness of the small intestine $(0.175$ $0.196 \mathrm{~g} / \mathrm{cm})$. The conclusion of this study is that the percentage of the amount of feed in the time schedule percentage of meal produces the final weight, carcass, carcass percentage, percentage of abdominal fat, and the thickness of the small intestine are the same. Percentage of ad libitum feed (without limits) every day produced the highest final weight and carcass of $638.80 \mathrm{~g} /$ head each and carcass weight $401.20 \mathrm{~g} /$ head.

Keywords: abdominal fats, body weight, carcass percentage, limiting feed, male laying hens

\section{PENDAHULUAN}

Ayam petelur jantan merupakan hasil ikutan penetasan ayam petelur komersial Impor dengan tujuan untuk menghasilkan daging. Pada saat penetasan tidak semua menghasilkan ayam betina saja, jika persentase diasumsikan $50 \%$ ayam betina, maka 50\% akan menghasilkan anak ayam jantan sehingga kesempatan ayam jantan $50 \%$ untuk dikembangkan sebagai pedaging. Hasil utama yang dimanfaatkan adalah ayam betina karena dipelihara dan disiapkan untuk menghasilkan telur, sedangkan ayam jantan dibuang dan dibakar atau untuk keperluan tertentu.

Di Indonesia ayam petelur jantan digunakan untuk menghasilkan daging dalam rangka mengejar pemenuhan protein hewani Indonesia yang masih rendah yaitu 5,6 g/kapita/hari dari target $15 \mathrm{~g} / \mathrm{kapita} / \mathrm{hari}$ (WNPG, 2012). Pemeliharaan ayam petelur jantan ini juga untuk membantu masyarakat dalam perekonomian dan memberikan kesempatan kerja yang lebih luas pada sektor peternakan dan juga permintaan masyarakat terhadap ayam kampung maka ayam petelur jantan dipelihara untuk memenuhi konsumsi protein, baik di keluarga dan di rumah makan. Konsumsi rumah makan telah banyak menjadikan ayam petelur jantan sebagai menu utama.

Ayam petelur jantan menjadi alternatif lain untuk ayam broiler dan ayam kampung yang kala itu sulit diperoleh bibitnya. Ayam petelur jantan rasanya mirip dengan ayam kampung, jadi dapat menggantikan ayam kampung yang sangat sulit didapatkan dan kendalanya harga ayam kampung mahal. Disinilah ayam petelur jantan dapat menggantikan ayam kampung, karena ayam kampung menyerupai ayam petelur jantan. Hal ini juga disampaikan oleh Riyanti (1995) menyatakan bahwa ayam petelur jantan rasanya mirip dengan ayam kampung, jadi dapat menggantikan ayam kampung yang sangat sulit didapatkan dan kendalanya harga ayam kampung mahal.

Dalampemeliharaanayampetelurjantan hal yang sangat penting adalah manajemen pemberian makan yang harus diperhitungkan waktu yang tepat agar penggunaan pakan yang digunakan lebih efesien. Untuk itu pemberian makan pada saat siang harus diperhatikan akibat suhu lingkungan yang meningkat dan menyebabkan konsumsi ransum terbuang dan disimpan dalam bentuk lemak. Santoso (2001) menyatakan bahwa program pembatasan pakan menurunkan penimbunan lemak pada ayam pedaging unsex. Untuk mengefisienkan pemberian pakan diperlukan jadwal waktu pemberian makan yang akan memberi dampak baik bagi pemeliharaan ayam petelur jantan.

Jadwal waktu pemberian makan pada ayam petelur jantan dilakukan untuk lebih mengefisiensikan cara proporsi persentase waktu makan yang dilakukan untuk mengurangi dampak negatif dari persentase 
pakan yang berlebihan dan pemborosan biaya produksi. Pemberian saat waktu makan akan berpengaruh terhadap pertumbuhan, pemberian waktu makan yang tepat akan menghasilkan bobot akhir yang baik. Bobot karkas berhubungan erat dengan pertumbuhan dan bobot akhir (Mugiyono, 2001). Respon nyata fisiologis ayam pedaging dinyatakan berdasarkan pencapaian penampilan akhir berupa hasil karkas dilihat dari perbedaan kondisi usus halusnya. Semakin baik respon ususpadaayamsemakinbaikpulapertumbuhan ayam tersebut yang tercermin pada hasil akhir yaitu persentase karkas (Novel et al., 2009). Rao et al. (2002) menyatakan bahwa selama cuaca panas, unggas harus dijauhkan dari ransum sementara karena suhu meningkat dan mencapai puncaknya. Pada cuaca yang panas unggas akan mengalami stress, akan menyebabkan penurunan konsumsi ransum sehingga terjadinya penurunan berat tubuh. Keadaan suhu lingkungan optimum untuk pertumbuhan berkisar antara $20-27^{\circ} \mathrm{C}$ dengan kelembaban berkisar antara 50-70\% (Borgest et al., 2004). Berdasarkan hasil penelitian Nova (2017) pembagian persentase pemberian ransum pada ayam jantan tipe medium dengan persentase $30 \%$ siang dan $70 \%$ malam memberikan pengaruh yang lebih baik terhadap bobot badan akhir ayam jantan tipe medium. Selanjutnya penelitian dari Hasan et al. (2013) menyatakan pembatasan pakan $75 \%$ dari standar frekuensi pemberian pakan yang berbeda yaitu 2 kali memberikan pengaruh penurunan lemak abdominal pada ayam boiler.

Beberapa penelitian sudah banyak dilakukan tentang porsi dan waktu makan, namun belum ada riset yang meneliti tentang bagaimana porsi dan waktu makan pada ayam petelur jantan dalam memenuhi kebutuhannya dan berapa kebutuhan sebernarnya ayam petelur jantan yang efesien, serta waktu yang tepat. Sehingga diketahui proporsi makan dan waktu pemberiannya yang dapat memberikan dampak pengaruh baik pada pertumbuhan ayam petelur jantan.

\section{METODE}

\section{Ternak Penelitian}

Anak ayam yang digunakan adalah (DOC) ayam petelur jantan strain Hy Line Brown ber umur sehari sejumlah 125 ekor, dengan berat DOC rata-rata 34 gram.

\section{Peralatan}

Kelengkapan penelitian digunakan dalam percobaan ini adalah tempat pakan (feeder), tempat air minum (waterer), lampu pijar $65 \mathrm{Watt} /$ boks digunakan sebagai sumber pemanas buatan, 1 buah lampu pijar 65 Watt sebagai penerang, ember, timbangan digital untuk menimbang, koran, kamera digital sebagai dokumentasi, thermometer, alas kandang, gunting, meteran, pisau, vaksin dan desinfektan.

\section{Ransum Percobaan}

Pakan yang dikonsumsi pada penelitian ini adalah pakan basal (Tabel 1 dan Tabel 2). Ransum basal adalah ransum yang diformulasikan atau diaduk sendiri.

\section{Kandang Percobaan.}

Kandang pemeliharaan yang digunakan adalah kandang box yang di sekat sebanyak 25 unit kandang dengan ukuran $0,7 \mathrm{~m} \times 0,7 \mathrm{~m}$ x $0,8 \mathrm{~m}$. Untuk bagian atas kandang ditutup dengan wareng. Setiap unit kandang berisi 5 ekor ayam petelur jantan.

Peralatan yang digunakan dalam penelitian ini adalah tempat pakan (feeder), tempat air minum (waterer), lampu pijar 65 Watt/boks digunakan sebagai sumber pemanas buatan, 1 buah lampu pijar 65 Watt sebagai penerang, ember, timbangan digital untuk menimbang, koran, kamera digital dan kamera handphone sebagai alat dokumentasi, alat penghitung (handcounter), thermometer, alas kandang, gunting, pisau, vaksin dan desinfektan.

\section{Rancangan Penelitian}

Metode penelitian ini dilakukan dengan metode eksperimen, menggunakan Rancangan Acak Lengkap (RAL) dengan 5 perlakuan persentase pakan dan 5 kali 
Tabel 1. Hasil analisis bahan penyusun ransum ayam petelur jantan

\begin{tabular}{lcccccc}
\hline Bahan Ransum & PK (\%) & LK $(\%)$ & SK $(\%)$ & Ca (\%) & P (\%) & ME (Kkal/kg) \\
\hline Jagung $^{\mathrm{a}}$ & 8,28 & 2,66 & 2,99 & 0,37 & 0,90 & 3.300 \\
Dedak $^{\mathrm{a}}$ & 12,90 & 4,09 & 16,15 & 0,69 & 0,26 & 1.640 \\
Tepung ikan $^{\mathrm{b}}$ & 35,81 & 1,52 & 2,80 & 5,50 & 2,88 & 3.080 \\
Bungkil kedelaic $^{\mathrm{c}}$ & 45,00 & 2,49 & 7,50 & 0,63 & 0,32 & 2.240 \\
Minyak kelapa & - & 100,00 & & - & - & 8.600 \\
Top Mix & - & & & 5,83 & 0,34 & - \\
\hline
\end{tabular}

Keterangan: ${ }^{a}$ Laboratorium Teknologi Industri Ternak Fakultas Peternakan Univesitas Andalas (2016)

${ }^{\mathrm{b}}$ Batubara (2012)

c. Scott et al. (1982)

Tabel 2. Kandungan nutrisi ransum penelitian

\begin{tabular}{lc}
\hline Kandungan Nutrisi Ransum & \\
\hline Protein kasar (\%) & 15,01 \\
Lemak (\%) & 4,75 \\
Serat kasar (\%) & 6,02 \\
Kalsium (\%) & 1,02 \\
Fosfor (\%) & 0,49 \\
Energi metabolisme (Kkal/kg) & 2896,40 \\
\hline
\end{tabular}

ulangan. Setiap unit percobaan terdapat 5 ekor ayam. Masing - masing perlakuan dibedakan oleh persentase jumlah persentase pakan pada jadwal persentase makan. Perlakuan akan diterapkan pada minggu ke -2 penelitian. berikut:

Setiap Perlakuan ditandai sebagai

T0: Jadwal pakan ad-libitum

T1: Jadwal pakan 30\% pagi - siang dan $70 \%$ sore - malam.

T2: Jadwal pakan $40 \%$ pagi - siang dan $60 \%$ sore - malam.

T3: Jadwal pakan 50\% pagi - siang dan 50\% sore - malam.

T4: Jadwal pakan $60 \%$ pagi - siang dan $40 \%$ sore - malam.

Keterangan:

Pagi - Siang : $07.00-15.00$ WIB

Sore - Malam : 15.05 - 23.05 WIB

Pakan diberikan ad-libitum pada umur 1-7 hari. Setelah itu pada umur $8-70$ hari dilakukan pemberian pakan sesuai perlakuan dengan frekuensi pemberian pakan yang sama dengan 4 kali pemberian pagi - siang dan 4 kali pemberian pada sore - malam dengan rentang waktu

Waktu pemberian pakannya yaitu pada pukul $07.00-07.10,09.00-09.10,11.00-$ 11.10 dan 13.00 - 13.10 pada pemberian pagi - siang dan pada pukul $15.05-15.15,17.05$ - 17.15, $19.05-19.15$ dan $21.05-21.15$ pada pemberian sore - malam.

Data yang diperoleh kemudian dianalisis dengan analisis ragam jika berbeda nyata pada taraf $1 \%$ dan $5 \%$ dilanjutkan dengan uji Duncan Multiple Range Test (DMRT), karena pengamatan menyeluruh pada setiap unit kandang, data dianalisis secara deskriptif.

Penempatan ayam pada setiap unit kandang dilakukan secara acak (random). Penempatan perlakuan proporsi pemberian pakan dalam petak kandang dilakukan secara 
Tabel 3. Pemberian ransum ayam petelur jantan

\begin{tabular}{cc}
\hline Umur (Minggu) & Konsumsi Ransum (g/ekor/hari) \\
\hline 1 & 12,1 \\
2 & 18,7 \\
3 & 24,2 \\
4 & 30,8 \\
5 & 38,4 \\
6 & 45,0 \\
7 & 51,7 \\
8 & 56,1 \\
9 & 60,4 \\
10 & 63,8 \\
\hline
\end{tabular}

Sumber: PT. Charoen Pokphand Indonesia (2003)

acak.

\section{Pemberian Pakan}

Pakan diberikan sesuai kebutuhan (Tabel 3) dengan perlakuan T0 : pemberian pakan ad libitum. T1 : Pemberian pakan $30 \%$ pagi - siang dan $70 \%$ sore - malam. $\mathrm{T} 2$ : Pemberian pakan $40 \%$ pagi - siang dan $60 \%$ sore - malam. T3 : Pemberian pakan $50 \%$ pagi - siang dan $50 \%$ sore - malam. T4 : Pemberian pakan $60 \%$ pagi - siang dan $40 \%$ sore - malam. Pada persiapan pemberian pakan semua penutup tempat pakan di pasang dan diganti dengan tempat pakan yang baru, setelah itu tutupnya dilepas untuk mendapatkan pemberian pakan yang serentak pada setiap unit kandang. Begitu seterusnya setiap pemberian pakan. Untuk pemberian pagi - siang yaitu dari pukul $07.00-15.10$ lalu sisa pakan di ambil dan ditimbang lalu diganti dengan tempat pakan baru yang sudah disiapkan sebelum pemberian pakan sore malam. Pada pemberian pakan sore - malam dari pukul 15.05 - 23.15 tempat pakan di angkat dan diturunkan dari kandang. Setiap pemberian pakan dilakukan penimbangan dan dicatat untuk mengetahui konsumsi ransum.

\section{Pemberian Minum}

Pada minggu pertama diberikan air minum yang di campur dengan gula untuk menghindari DOC dari stres. Pembersihan dan pencucian tempat air minum dilakukan setiap hari.

\section{Kebersihan Kandang}

Untuk menjaga kebersihan kandang dari kotoran dan sisa pakan, kandang dibersihkan setiap pagi dan sore hari.

\section{Pencucian Peralatan}

Pencucian peralatan kandang seperti tempat pakan dan minum dicuci setiap hari.

\section{Sanitasi Perlengkapan}

Perlengkapan yang digunakan selama pemelihraan dibersihkan menggunakan detergen setiap hari dan membersihan lingkungan sekitar kandang perlu dilakukan setiap hari, agar ayam petelur jantan terhindar dari bibit penyakit. Kotoran ayam petelur jantan yang bertumpukan dibersihkan 2 kali dalam seminggu untuk menghindari tingginya amoniak dalam kandang.

\section{Tempat dan Waktu Penelitian}

Penelitian ini dilakukan dikandang unggas Laboratorium Percobaan dan Laboratorium Produksi Unggas Fakultas Peternakan Universitas Andalas Padang selama 10 minggu, yang dimulai pada tanggal 5 Desember 2017 sampai tanggal 18 Februari 2018.

\section{Parameter Penelitian}

1. Bobot akhir ayam petelur jantan diperoleh dengan cara menimbang ayam petelur 
jantan sebelum dipotong.

2. Bobot karkas dapat diketahui dari hasil penimbangan bobot akhir ternak dikurangi kepala, leher, kaki, bulu, jeroan, dan darah.

3. Persentase karkas ditentukan berdasarkan perbandingan antara bobot karkas pada waktu pemotongan dengan bobot akhir kemudian dikali 100\%.

4. Persentase lemak abdomen (dihitung dalam persen). Persentase lemak abdomen diperoleh dari hasil perbandingan antara bobot lemak abdomen (gram) dengan bobot ahir (gram) dikalikan 100\%.

5. Ketebalan usus halus $(\mathrm{g} / \mathrm{cm})$ diperoleh dengan cara pembagian berat usus halus dengan panjang usus halus.

\section{Analisa Data}

Setelah semua data yang terkumpul sesuai dengan parameter yang diukur, dilakukan uji statistik keragaman sesuai dengan rancangan yang digunakan.Hasil analisis sidik ragam menunjukkan $\mathrm{F}$ hitung $>$ F tabel pada taraf nyata uji $(\alpha) 5 \%$, sehingga dilakukan uji lanjut dengan menggunakan uji Ducan Multiple Range (DMRT) guna mengetahui antar perlakuan berbeda (Steel and Torrie, 1991).

\section{HASIL DAN PEMBAHASAN}

\section{Rataan Perlakuan Pada Bobot Akhir Penelitian}

Rataan bobot akhir ayam petelur jantan untuk masing-masing perlakuan dapat dilihat pada Tabel 4. Berdasarkan hasil analisis keragaman bobot akhir diperoleh bahwa persentase jumlah pemberian pakan pada jadwal waktu pemberian makan berpengaruh sangat nyata $(\mathrm{P}<0,01)$ terhadap bobot akhir ayam petelur jantan.

Dari hasil penelitian ini didapatkan rataan bobot akhir berkisar antara 562,08$638,80 \mathrm{~g} /$ ekor. Hasil penelitian ini lebih tinggi dari hasil penelitian Ariesta et al. (2015) bobot akhir ayam kampung selama 10 minggu yaitu 383,33-620,75 g/ekor dan hasil dari penelitian
Suartiningsih et al. (2017) mengatakan bobot akhir ayam kampung umur 10 minggu berkisar antara 462,04-468,36 g/ekor. Akan tetapi lebih rendah dari penelitian Aryanti et al. (2013) bobot akhir ayam kampung umur 10 minggu berkisar 800-900 g/ekor dan Jaya (2009) mengatakan bobot akhir ayam petelur jantan 970 g/ekor. Tingginya bobot akhir ini disebabkan karena tingginya konsumsi ransum yang dikonsumsi. Salah satu faktor yang mempengaruhi bobot akhir adalah konsumsi ransum.

Hasil uji Duncan Multiple Range Test (DMRT) diperoleh bahwa perlakuan T0 berbeda sangat nyata $(\mathrm{P}<0,01)$ terhadap $\mathrm{T} 1$, T2, T3, dan T4. Hasil uji Duncan Multiple Range Test (DMRT) juga menunjukkan bahwa antara perlakuan T1, T2, T3, dan T4 berbeda tidak nyata $(\mathrm{P}>0,05)$. Hal ini menunjukkan persentase jumlah persentase pakan pada jadwal waktu persentase pemberian makan belum mampu menyamai bobot akhir pada pemberian pakan adlibitum (tanpa batas).

Tidak terdapatnya perbedaan secara nyata $(\mathrm{P}>0,05)$ pada jadwal jumlah persentase pakan ini disebabkan karena kesempatan makan ayam lebih sedikit dari ayam persentase pakan adlibitum (T0). Fungsi ransum yang diberikan pada ayam pada prinsipnya memenuhi kebutuhan pokok untuk hidup dan membentuk sel-sel jaringan. Pada ayam yang diberikan persentase jumlah pemberian pakan lebih banyak atau pun lebih sedikit pada pagi-siang dan sore-malam tidak memberikan respon yang baik bagi pertumbuhan hal ini disebabkan karena pola makannya terganggu karena belum mampu memenuhi kebutuhannya.

Pada saat pakan di ambil pukul 23.0007.00 sehingga kesempatan ayam makan dalam mengkonsumsipakan berkurang, karena pada malam hari ini adalah suhu nyaman untuk pertumbuhan dalam mengkonsumsi pakan. Ransum yang di konsumsi pada malam hari lebih banyak sangat efisien dan akan dialokasikan untuk pembentukan jaringan tubuh. Borgest et al. (2004) menyatakan keadaan suhu yang optimum bagi ayam 
Tabel 4. Rataan bobot akhir ayam petelur jantan

\begin{tabular}{lc}
\hline Perlakuan & Bobot Akhir $(\mathrm{g} / \mathrm{e})$ \\
\hline T0 (ad-libitum) & $638,80^{\mathrm{A}}$ \\
T1 (30\% pagi - siang 70\% sore - malam) & $562,08^{\mathrm{B}}$ \\
T2 (40\% pagi - siang 60\% sore - malam) & $570,92^{\mathrm{B}}$ \\
T3 (50\% pagi - siang 50\% sore - malam) & $565,88^{\mathrm{B}}$ \\
T4 (60\% pagi - siang 40\% sore - malam) & $578,88^{\mathrm{B}}$ \\
\hline Standar Eror & 8,25 \\
\hline
\end{tabular}

Keterangan: Huruf besar pangkat berbeda menurut baris, menunjukkan hasil yang berbeda sangat nyata $(\mathrm{P}<0,01)$

adalah malam hari karena suhu udara tidak lagi panas seperti siang hari berkisar antara $20-27^{\circ} \mathrm{C}$ dengan kelembaban berkisar antara $50-70 \%$.

Pada saat kebutuhan energinya belum terpenuhi maka ayam akan mengalami kelaparan hal ini disebabkan karena isi temboloknya yang hampir habis atau pun sudah habis, maka akan dikirim sinyal ke susunan saraf pusat yang menandakan bahwa ayam tersebut lapar. Ketika keterbatasan dalam jadwal mengkonsumsi pakan maka cadangan nutrisi dalam tubuh digunakan untuk menghasilkan energi, guna menjalankan fungsi-fungsi dalam tubuh. Maulida (2004) mengatakan protein diperuntukan untuk pertumbuhan digunakan untuk energi keperluan tubuh sehingga semula untuk pertumbuhan jadi terhambat.

Aziz et al. (2011) menyampaikan bahwa terjadinya penurunan pertambahan bobot badan disebabkan karena suplai energi terbatas nutrisi yang berguna untuk menunjang bertumbuhnya jaringan, produksi hormone tiroksin yang berhubungan dengan aktivitas enzim yang menyokong pertumbuhan. Nilai pakan yang dibagi pada jadwal sesuai dengan keperluan ayam agar pertumbuhan tidak terhambat dan mengasilkan bobot badan bertambah. Sesuai dengan pendapat Anggorodi (1994) menyatakan pemberian pakan pada waktu tertentu disesuaikan dengan keadaan ayam, jumlah yang diberikan jangan sampai kurang dari kebutuhan, sebab dapat menghambat pertumbuhan.
Rataankonsumsiransumpada penelitian ini adalah T0 (2419,56 g/ekor), T1 (2121,56 g/ekor), T2 (2232,08 g/ekor), T3 (2145,96 g/ekor), dan T4 (2234,52 g/ekor). Siregar et al. (1982) menyatakan bahwa jumlah ransum yang dikonsumsi akan mempengaruhi bobot hidup yang diperoleh, semakin banyak ransum yang dikonsumsi semakin meningkat bobot hidup yang dihasilkan. Konsumsi ransum yang relatif banyak akan menyebabkan zatzat makanan seperti asam amino, vitamin, protein dapat mencukupi kebutuhan ayam untuk memenuhi kebutuhan hidup pokok dan pertumbuhan terpenuhi untuk menghasilkan performans yang baik.

Tingginya bobot akhir ayam pada perlakuan T0 disebabkan karena pemberian pakan ad libitum (tanpa batas) menunjukkan konsumsi yang tertinggi dari perlakuan lainnya, sehingga menghasilkan bobot akhir yang tertinggi dan konsumsi ransum juga menunjukkan berbeda sangat nyata. Kualitas ransum, jenis ransum, serta lama pemeliharaan juga aktivitas merupakan unsur unsur yang sangat mempengaruhi bobot badan (Soeparno, 2015). Sesuai dengan pendapat Anggorodi (1994) yang menyatakan bahwa salah satu faktor yang berperan penting dalam mempengaruhi laju pertumbuhan adalah konsumsi.

Ransum ayam pada perlakuan T0 mampu mengoptimalkan pakan yang tersedia sepanjang hari untuk proses pertumbuhan. Penyediaan pakan secara adlibitum atau ayam akan makan jadwal yang tanpa dibatasi maka 
Tabel 5. Rataan bobot karkas ayam petelur jantan

\begin{tabular}{lc}
\hline Perlakuan & Rataan Karkas $(\mathrm{g} / \mathrm{e})$ \\
\hline T0 (ad-libitum) & $401,20^{\mathrm{A}}$ \\
T1 (30\% pagi - siang 70\% sore - malam) & $337,80^{\mathrm{B}}$ \\
T2 (40\% pagi - siang 60\% sore - malam) & $347,40^{\mathrm{B}}$ \\
T3 (50\% pagi - siang 50\% sore - malam) & $343,40^{\mathrm{B}}$ \\
T4 (60\% pagi - siang 40\% sore - malam) & $356,40^{\mathrm{B}}$ \\
\hline Standar Eror & 9,29 \\
\hline
\end{tabular}

Keterangan: Huruf besar pangkat berbeda menurut baris, menunjukkan hasil yang berbeda sangat nyata $(\mathrm{P}<0,01)$

ternak dapat makan setiap waktu berdasarkan kebutuhan ayam. Kartasudjana dan Suprijatna (2006), mengatakan bahwa ayam akan terus makan jika kebutuhan energi belum terpenuhi. Wahju (1992), menambahkan pertumbuhan menyokong aktivitas diperlukan energi dalam konsumsi yang di makan serta mempertahankan panas tubuh yang homoiterm yang normal.

Berdasarkan hasil analisis keragaman bobot karkas Tabel 5 diperoleh bahwa pembatasan persentase jumlah pemberian pakan pada jadwal waktu pemberian makan berpengaruh sangat nyata $(\mathrm{P}<0,01)$ terhadap bobot karkas ayam petelur jantan.

Rataan bobot karkas yang dihasilkan pada penelitian ini adalah $337,80-401,20 \mathrm{~g} /$ ekor. Penelitian ini diperoleh lebih tinggi dari hasil penelitian Suartiningsih et al. (2017) mengatakan bobot karkas ayam kampung umur 10 minggu berkisar antara 282,38295,78 g/ekor. Akan tetapi lebih rendah dari hasil penelitian Kurniawan (2011) yang menyatakan bobot karkas ayam kampung umur 10 minggu berkisar 397,67-620,39 g/ ekor. Tingginya bobot karkas ini disebabkan karena tingginya konsumsi pakan yang menyebabkan tingginya bobot akhir dan bobot karkas yang dihasilkan.

Hasil uji Duncan Multiple Range Test (DMRT) diperoleh bahwa perlakuan T0 berbeda sangat nyata $(\mathrm{P}<0,01)$ terhadap $\mathrm{T} 1$, T2, T3, dan T4. Hasil uji Duncan Multiple Range Test (DMRT) juga menunjukkan bahwa antara perlakuan $\mathrm{T} 1, \mathrm{~T} 2, \mathrm{~T} 3$ dan $\mathrm{T} 4$ berbeda tidak nyata $(\mathrm{P}>0,05)$. Hal ini menunjukkan persentase jumlah persentase pakan pada jadwal waktu persentase makan belum mampu menyamai bobot karkas persentase pakan adlibitum (tanpa batas).

Berbeda tidak nyata $(\mathrm{P}>0,05)$ pada persentase jumlah pemberian pakan pada jadwal waktu pemberian makan ini disebabkan karena terdapatnya perbedaan yang tidak nyata pula terhadap konsumsi ransum dan bobot akhir, dan bobot non karkas yang terbuang tidak berbeda antar perlakuan terlihat dari perbandingan bobot akhir dikurang bobot karkas, sehingga menghasilkan bobot karkas yang sama saja. Karkas merupakan hasil potongan ayam bersih setelah dikeluarkan bulu, darah, kepala, leher, kaki, cakar, dan organ dalam (Leeson dan Sumers, 1980). Ahmad dan Herman (1982) menyatakan bobot karkas sejalan bobot hidup, semakin tinggi bobot hidup maka karkas akan semakin tinggi. Grey et al. (1982), menyatakan ayam jantan dan betuna, umur mempengaruhi bobot badan dan karkas ditambahkan ada beberapa faktor-faktor lain yang dapat mempengaruhi diantaranya strain, makanan, manajemen, dan lingkungan.

Berbeda sangat nyata $(\mathrm{P}<0,01)$ pada pemberian pakan adlibitum (T0) hal ini disebabkan karena setelah disembelih dibului, tanpa darah, leher, kaki dan organ dalam menghasilkan bobot karkas yang tertinggi. Meskipun hasil ikutan (non karkas) yang dibuang cenderung lebih besar dari pada 
Tabel 6. Rataan persentase karkas ayam petelur jantan

\begin{tabular}{lc}
\hline Perlakuan & Persentase Karkas (\%) \\
\hline T0 (ad-libitum) & 62,76 \\
T1 (30\% pagi - siang 70\% sore - malam) & 60,10 \\
T2 (40\% pagi - siang 60\% sore - malam) & 60,85 \\
T3 (50\% pagi - siang 50\% sore - malam) & 60,78 \\
T4 (60\% pagi - siang 40\% sore - malam) & 61,52 \\
\hline Standar Eror & 0,33 \\
\hline
\end{tabular}

Keterangan: Perlakuan berpengaruh tidak nyata terhadap persentase karkas $(\mathrm{P}>0,05)$

perlakuan lainnya namun masih tergolong tinggi karena bobot akhirnya yang tinggi. Rasyaf (2003) menyatakan bobot hidup dengan berat karkas berhubungann positif, semakin bertambah bobot hidup produksi karkas akan semakin bertambah. Williamson dan Payne (1978) menyatakan, bahwa bangsa, jenis kelamin, umur, berat badan, dan makanan merupakan faktor yang mempengaruhi karkas.

\section{Pengaruh Perlakuan Pada Persentase Karkas}

Rataan persentase karkas ayam petelur jantan untuk masing-masing perlakuan dapat dilihat pada Tabel 6. Berdasarkan hasil analisis keragaman persentase karkas, diperoleh bahwa persentase jumlah pemberian pakan pada jadwal waktu pemberian makan menunjukkan berpengaruh tidak nyata $(\mathrm{P}>0,05)$ terhadap persentase karkas ayam petelur jantan.

Rataan persentase karkas pada penelitian ini berkisar antara $60,10 \%-62,76 \%$. Persentase karkas ayam petelur jantan yang dihasilkan pada penelitian ini masih berada dalam kisaran normal. Bobot karkas normal adalah $60-75 \%$ dari bobot tubuh (Siregar et al., 1982). Hasil penelitian ini juga berada pada kisaran yang diperoleh Suartiningsih et al. (2017) persentase karkas umur 10 minggu pada ayam kampung berkisar antara 60,74$63,13 \%$.

Berpengaruh tidak nyata $(\mathrm{P}>0,05)$ persentase jumlah pemberian pakan pada perlakuan T1, T2, T3 dan T4 hal ini disebabkan karena terdapatnya perbedaan yang tidak nyata juga terhadap bobot akhir dan bobot karkas, sehingga perbandingan antara bobot karkas dan bobot hidup juga sama. Sesuai dengan pendapat Dwiyanto et al. (1997) bahwa karkas ayam sanagt erat hubungannya dengan bobot hidup, semakin bertambah bobot hidup maka produksi karkas akan meningkat demikian pula denkian bobot hidup yang sama akan maka hasil bobot karkas sama. Mulyono (1997) berpendapat bahwa umur, berat badan, perlemakan, kualitas dan kuantitas pakan, serta isi saluran pencernaan akan mempengaruhi berat karkas. Pada pemberian pakan adibitum (T0) juga menunjukkan berpengaruh tidak nyata $(\mathrm{P}>0,05)$ hal ini disebabkan karena bobot akhir yang tinggi berbanding lurus dengan bobot non karkas yang yang terbuang memiliki berat yang tinggi juga seperti kepala, leher, darah, kaki, jeroan dan lemak, sehingga perbandingan bobot karkas dan bobot akhir tidak terlalu besar dihasilkan. Harisshinta (2009) berpendapat bahwa berat bukan karkas berkolerasi positif dengan berat karkas dan bobot hidup, semakin tinggi bobot hidup maka semakin tinggi pula berat karkas dan bagian bukan karkas. Menurut Daryanti et al. (1982) dan Wahidayatun (1983) menyatakan bahwa persentase karkas dipengaruhi oleh besarnya persentase bagian tubuh yang terbuang serta bagian diluar karkas. Lemak abdomen berpengaruh tidak nyata namun pada ayam perlakuan T0 ini persentase lemak abdomen juga menunjukkan persentase lemak abdomen meningkat sehingga mengurangi berat dari karkas. Dewanti et al. (2013) menyatakan bahwa bertambahnya berat badan cenderung meningkatnya berat lemak abdominal. 
Tabel 7. Rataan persentase lemak abdomen ayam petelur jantan

\begin{tabular}{lc}
\hline Perlakuan & Berat Lemak Abdomen (\%) \\
\hline T0 (ad-libitum) & 1,15 \\
T1 (30\% pagi - siang 70\% sore - malam) & 0,80 \\
T2 (40\% pagi - siang 60\% sore - malam) & 0,72 \\
T3 (50\% pagi - siang 50\% sore - malam) & 0,73 \\
T4 (60\% pagi - siang 40\% sore - malam) & 0,79 \\
\hline Standar Eror & 1,19 \\
\hline
\end{tabular}

Keterangan: Perlakuan berpengaruh tidak nyata terhadap persentase lemak abdomen $(\mathrm{P}>0,05)$

Waskito (1981) mengemukakan bahwa faktor lain yang mempengaruhi persentase karkas berkorelasi terbalik dengan lemak abdominal dimana apabila semakin tinggi lemak abdominal maka persentase karkas akan semakin menurun.

Ayam pada perlakuan T0 yang memiliki bobot akhir dan bobot karkas yang tinggi menunjukkan ayam tidak terjadi upaya kegemukan pada umur ini masih berada dalam kestabilan berat badan. Persentase karkas di pengaruhi oleh ukuran tubuh dan derajat kegemukan. Ternak yang gemuk persentase karkasnya tinggi dan umumnya berbentuk tebal seperti balok. Faktor-faktor yang mempengaruhi presentase karkas adalah pakan, umur, bobot hidup, jenis kelamin, hormon, bangsa dan konformasi tubuh (Preston dan Willis, 1974).

\section{Pengaruh Perbedaan Pemberian Pakan Adlibitum dan Jadwal Terhadap Persentase Lemak Abdomen}

Rataan persentase lemak abdomen ayam petelur jantan untuk masing- masing perlakuan dapat dilihat pada Tabel 7 . Berdasarkan hasil analisis keragaman persentase lemak abdomen diperoleh bahwa pengaruh antara persentase jumlah pemberian pakan pada jadwal waktu pemberian makan berpengaruh tidak nyata $(\mathrm{P}>0,5)$ terhadap persentase lemak abdomen ayam petelur jantan.Persentase lemak abdomen diperoleh dari perbandingan berat lemak abdomen dengan bobot hidup ayam petelur jantan kemudian dikali 100\% (Siregar et al., 1982).
Hasil penelitian ini diperoleh rataan persentase lemak abdomen berkisar antara $0,72-1,16 \%$. Hasil ini lebih tinggi dari penelitian Thalele et al. (2018) persentase lemak abdomen ayam kampung super umur 11 minggu berkisar antara 0,10-0,73\% dari berat hidup. Hasil yang didapat masih berada dikisaran yg diperoleh Becker et al. (1979) bahwa persentase lemak abdomen berkisar antara 0,73-3,78\% dari bobot hidup.

Pada persentase lemak abdomen ayam petelur jantan berpengaruh tidak nyata $(\mathrm{P}>0,05)$ disebabkan karena ayam petelur jantan pada umur 10 minggu masih dalam masa pertumbuhan, masih belum adanya lemak abdomen karena tidak terjadi kelebihan energi pada ayam pelakuan $\mathrm{T} 1$, $\mathrm{T} 2$, T3, dan T4 yang disimpan dalam bentuk lemak karena zat-zat makanan diserap oleh tubuh masih digunakan untuk pertumbuhan. Energi yang didapatkan lebih banyak dimanfaatkan untuk pembentukkan daging (karkas) sehingga hanya sedikit dalam pembentukkan untuk lemak abdomennya. Rasyaf (2003) yang menjelaskan bahwa pada dasarnya pembentukan lemak terjadi karena kelebihan konsumsi energi, menambahkan bahwa timbunan lemak terjadi seiring dengan bertambahnya umur ternak.

Lemak abdomen dapat meningkat juga karena pada saat ayam mengalami keterbatasan dalam mengkonsumsi pakan, energi pada pakan digunakan untuk sintesis lemak.Sesuai dengan hasil penelitian Hasan et al. (2013) mengatakan jika ayam di puasakan atau dibatasi konsumsinya maka maka energi 
Tabel 8. Rataan ketebalan usus halus ayam petelur jantan

\begin{tabular}{lc}
\hline Perlakuan & Ketebalan Usus $(\mathrm{g} / \mathrm{cm})$ \\
\hline T0 (ad-libitum) & 0,1955 \\
T1 (30\% pagi-siang 70\% sore - malam) & 0,1752 \\
T2 (40\% pagi -siang 60\% sore - malam) & 0,1775 \\
T3 (50\% pagi - siang 50\% sore - malam) & 0,1930 \\
T4 (60\% pagi - siang 40\% sore - malam) & 0,1799 \\
\hline Standar Eror & 0,0058 \\
\hline
\end{tabular}

Keterangan: Perlakuan berpengaruh tidak nyata terhadap ketebalan usus halus $(\mathrm{P}>0,05)$

dibutuhkan untuk sintesa lemak berguna untuk mempertahankan suhu tubuh agar suhu tubuh itu dapat bertahan. Kita mengetahui bahwa ayam makan untuk memenuhi kebutuhan energi tubuh. Hal ini dikarenakan pada saat puasa, energi dari pakan lebih banyak digunakan untuk sintesis lemak demi mempertahankan termoregulasi tubuh. Sesuai dengan pendapat Wiliamson dan Payne (1993), bahwa ternak unggas termasuk ayam, mempunyai kemampuan mempertahankan suhu tubuhnya dari berbagai suhu lingkungan yang bervariasi disebut juga dengan ternak homoitermis.

Ayam pada persentase pakan ad libitum (T0) menunjukkan persentase lemak abdomen berpengaruh tidak nyata namun terjadi peningkatan persentase lemak abdomen dari pada ayam dengan perlakuan persentase jumlah persentase pakan T1, T2, T3, dan T4 hal ini disebabkan proses metabolisme dari tubuh melebihi tingkat kebutuhan ternak. Anggorodi (1985) menyatakan jika ayam mengkonsumsi energi berlebihan makan akan terjadi penimbunan lemak dalam tubuh terutama daerah abdomen. Haro (2005) menambahkan bahwa dalam tubuh ternak terjadi pemecahan lemak (lipolysis). Lemak dalam tubuh berasal dari pakan yang di konsumsi, sedangkan proses lipolysis itu dikatalis oleh enzim lipase yang diatur hormone yang komplek.

\section{Ketebalan Usus Halus}

Rataan ketebalan usus halus ayam petelur jantan untuk masing-masing perlakuan dapat dilihat pada Tabel 8. Berdasarkan hasil analisis keragaman ketebalan usus halus diperoleh bahwa pengaruh persentase jumlah pemberian pakan pada jadwal waktu pemberian makan berpengaruh tidak nyata $(\mathrm{P}>0,05)$ terhadap ketebalan usus halus ayam petelur jantan.Rataan ketebalan usus halus pada penelitian ini berkisar antara 0,1752 - 0,1955 g/cm.Tebal usus halus ditentukan berdasarkan perbandingan antara berat usus halus dengan panjang usus halus. Hasil penelitian ini lebih tinggi dari penelitian Mardika (2017) mengatakan ketebalan usus pada ayam broiler berkisar antara $0,1465-$ $0,1626 \mathrm{~g} / \mathrm{cm}$.

Berpengaruh tidak nyata $(\mathrm{P}>0,05)$ di semua perlakuan ini pada ketebalan usus halus ayam petelur jantan hal ini disebabkan karena penyerapan makanan pada usus halus tidak memberikan pengaruh secara nyata terhadap ukuran usus halus. Meskipun ayam pada perlakuan T0 mengkonsumsi pakan lebih banyak namun tidak mempengaruhi secara nyata terhadap ketebalan usus halus. Sesuai dengan pendapat Amrullah (2003) menambahkan bahwa ukuran usus bahwa ukuran panjang, tebal dan bobot saluran pencernaan unggas bias berubah sasuai dengan keadaan pakan yang di konsumsi.

Pembatasan persentase pakan dengan persentase jumlah persentase pakan pada perlakuan T1, T2, T3, dan T4mampumenyamai perlakuan persentase pakan ad libitum (T0) pada penyerapan makanan di dalam usus halus, walaupun hasil menunjukkan berpengaruh tidak nyata terhadap ketebalan usus halus, namun pemberian pakan secara adlibitum pada perlakuan T0 mampu menghasilkan 
berpengaruh sangat nyata terhadap bobot akhir ayam peterlur jantan sehingga ketebalan ususnya meningkat. Hal ini disebabkan karena konsumsi yang banyak sehingga penyerapan zat makanan untuk pertumbuhan lebih banyak namun berpengaruh tidak nyata terhadap ukuran dan bentuk usus halus. Seperti yang dikatakan sebelumnya oleh Amrullah (2003) sebelumnya bahwa ukuran panjangdan bobot saluran pencernaan unggas bukan besaran statis. Menurut Kamal (1994), usus halus dapat berkembang tergantung pada serat dalam konsumsi ransum.

Meningkatnya panjang dan berat usus halus, semakin meningkat pula permukaan bagian dalam dan luas permukaan usus halus, sehingga dalam taraf tertentu terjadi peningkatan daya cerna dan daya serap sarisari makanan oleh usus halus (Yao et al., 2006). Shapira dan Nir (1995) menambahkan jumlah pakan yang dikonsumsi sangat erat hubungan dengan pertumbuhan organ pencernaan, ditambahkan lagi bahwa keaktifan organ pecernaan diakibatkan dengan jumlah kosumsui ransum dapat merangsang pertumbuhannya.

Kemampuan ini didukung usus yang lembut dan menonjol seperti jari (vili), sehingga penyerapan zat-zat makanan akan maksimal untuk pertumbuhan. Semakin luas vili usus halus maka semakin banyak zat-zat makanan yang bisa diserap yang akhirnya dapat berdampak pada pertumbuhan organorgan tubuh dan karkas yang meningkat (Asmawati, 2013). Hasil akhir pada persentase karkas karena respon usus halus semakin baik akan berdampak pada pertumbuhan ayam (Novel et al., 2009).

\section{KESIMPULAN}

Berdasarkan hasil dari penelitian disimpulan bahwa pakan diberikan secara adlibitum menghasilkan berat akhir dan berat karkas tertinggi sedangkan presentase jadwal pakan pada ayam petelur jantan, persentase makan menghasilkan bobot akhir, karkas, persentase karkas, persentase lemak abdomen dan ketebalan usus halus yang sama. Untuk mendapatkan bobot akhir yang efesien disarankan ayam petelur jantan diberikan pakan secara adlibitum.

\section{DAFTAR PUSTAKA}

Ahmad, B. H. dan Herman, R. 1982. Perbandingan produksi antara ayam kampung dan ayam petelur.Media Peternakan 7:19-34.

Amrullah, I. K. 2003. Nutrisi Ayam Petelur. Lembaga Satu Gunung Budi. Bogor.

Anggorodi. 1985. Kemajuan Mutakhir dalam Ilmu Makanan Ternak Unggas. Cet, Ke-1. Universitas Indonesia, Jakarta.

Anggorodi. 1994. Ilmu Makanan Ternak Umum. Penerbit Gramedia. Jakarta

Ariesta, A. H., I. G. Mahardika, dan G. A. M. K. Dewi. 2015. Pengaruh level energi dan protein ransum terhadap penampilan ayam kampung umur 1-10 minggu. Laporan Penelitian Hibah Bersaing. Fakultas Peternakan. UNUD, Denpasar.

Aryanti, F., Aji. M. B. dan Budiono. N. 2013. Pengaruh pemberian air gula merahterhadap performans ayam kampung pedaging. Jurnal Sains Veteriner. ISSN. 31 (2):0126-0421.

Asmawati. 2013. The effect of in ovo feeding on hatching weight and small intestinal tissue development of native chicken. (Disertasi) Fakultas Peternakan Universitas Hasanuddin. Makassar.

Aziz, A., H. Abbas, Y. Heryandi, dan E. Kusnadi. 2011. Pertumbuhan kompetensi dan efesiensi produksi ayam broiler yang mendapat pembatasan waktu makan. Media Peternakan, April 2011, hlm. 50-57. EISSN 2087-4634.

Batubara, L. 2012. Pengaruh penggunaan jamur tiram (Pleuterus ostreatus) dalam ransum terhadap total kolestrol, HDL, LDL plasma darah ayam 
broiler. Skripsi. Fakultas Peternakan Universitas Andalas, Padang.

Becker, W. A., J. V. Spencer, L. W. Minishand, and J. A. Warstate. 1979. Abdominal and carcas fatfive broiler strain. Poult. Sci. 60:692-697.

Borgest, S. A., F. Da Silva, A. Maiorka, D. M. Hooge, and K. R. Cummings. 2004. Effects of diet and cyclic daily heat stress on electrolyte, nitogen and water intake, excretion and retention by colostomized male broiler chickens. Int J Pount Sci. 3:313-321.

Daryanti, B. Achmad, dan R. Herman. 1982. Perbandingan produksi daging antaraayam jantan petelur dan ayam jantan pedaging. Media Peternakan. FakultasPeternakan. Institut Pertanian Bogor, Bogor.

Dewanti, R., M. Irham, dan Sudiyono. 2013. Pengaruh penggunaan eceng gondok (Eichorniacrassipes) terfermentasi dalam ransum terhadap persentasekarkas, nonkarkas danlemak abdominal itik lokal jantan umur delapan minggu. Buletin Peternakan 37(1):19-25.

Dwiyanto, K. A. L., Sabrani, dan B. Sitorus. 1997. Performa Ayam Pedaging (Broiler). Yayasan Pustaka Nusantara. Yogyakarta.

Grey, T. C., D. Robinson, and J. M. Jones. 1982. Effect of age and sex on the eviscerated yield, muscle and edible offal of commercial broiler strain. Poultry Sci. 57:1198-1203.

Haro, C. V. 2005. Interaction between dietary polyunsaturated fatty acids and vitamin $\mathrm{E}$ in body lipid composition and $\alpha$-tocopherol content of broiler chickens. Thesis. Universitat Autonoma de. Barcelona. Spain.

Hasan, N. F., U. Atmomarsono, dan E. Suprijatna. 2013. Pengaruh freuensi pemberian pakan pada pembatasan pakan terhadap bobot akhir, lemak abdominal, dan kadar lamak hati ayam broiler. Animal Agriculcuture Journal, Vol. 2. No. 1: 336-343.

Harisshinta, R. 2009. Pengaruh penggunaan limbah teh dalam pakan terhadap persentase karkas, lemak abdominal, kandungan lemak daging dan berat organ dalam ayam pedaging. Fakultas Peternakan Universitas Brawijaya, Malang.

Jaya, R. 2009. Standar Performan Produksi Ayam Jantan Tipe Petelur per 1000 Ekor. Bandar Lampung.

Kamal, M. 1994. Nutrisi Ternak I. Fakultas Peternakan, Universitas Gadjah Mada, Yogyakarta.

Kartasudjana, R. dan E. Suprijatna. 2006. Manajemen Ternak Unggas. Penebar Swadaya. Jakarta.

Kurniawan, H. 2011. Karkas dan potongan karkas ayam kampung umur 10 minggu yang diberi ransum mengandung bungkil biji jarak pagar (Jatropra curcas L) terfermentasi Rhizopus oligosporus. Fakultas Peternakan Intitut Pertanian Bogor. Bogor.

Laboratorium Teknologi Industri Ternak. 2016. Fakultas Peternakan. Universitas Andalas.

Lesson, S. And D. J. Summers. 1980. Production and carcass characteristic of broiler chicken. Poultry Sci. 59:562567.

Mardika, H. 2017. Pengaruh penampilan probiotik campuran (Pediococcus pentosaceus, saccharomyces cerevisilae, dan aspergillus oryzae) dalam air minum terhadap total kolestrol darah,ketebalan usus halus, dan panjang usus halus. Skripsi. Fakultas Peternakan. Universitas Andalas, Padang.

Maulinda. 2004. Pengaruh pembatasan pakan terhadap performan,bobot karkas dan non karkas pada itik afkhir. Skripsi Jurusan Produksi Ternak Fakultas Pertanian. Universitas Sebelas Maret. 
Mugiyono, S. 2001.Pengaruh serasah terhadap penampilan produksi dan kualitas ayam broiler. Laporan Penelitian Fakultas Peternakan. Universitas Jendral Soedirman. Purwokerto.

Mulyono. 1997. Beternak Ayam Arab. Kanisius. Yogyakarta.

Nova, K. 2017. Performa ayam jantan tipe medium pangan persentase pemberian ransum yang berbeda antara siang dan malam. Prosiding Seminar Nasional Pengembangan Teknologi Pertanian. Politeknik Negeri Lampung, Lampung. Halaman 307-312.

Novel, D. J., J. W. Ng'ambi, D. Norris, and C. A. Mbajiorgu. 2009. Effect of different feed restriction regimes during the starter stage on productivity and carcass characteristics of male andfemale Ross 308 broiler chickens. J. Poult. Sci. 8 (1):35-39.

PT. Charoen Pokphan Indonesia, Tbk. 2003. Manual Broiler Manajemen CP.707. Jakarta

Preston, T. R. and M. B. Willis. 1974. Intensive Beef Production. Pergamon Press. Oxford. New York. Toronto. Sydney.

Rao, R. S. V., D. Nagalashmi, dan V. R. Redy. 2002. Feeding to minimize heat stress. J. Poultry Int 41: 7-15.

Rasyaf, M. 2003. Beternak Ayam Pedaging. Penebar Swadaya, Jakarta. Utama. Jakarta.

Riyanti. 1995. Pengaruh berbagai imbangan energi protein ransum terhadap peforman ayam petelur jantan tipe medium. Prosiding Seminar Nasional Sains dan Teknologi Peternakan. Balai Penelitian Ternak. Ciawi. Bogor.

Santoso, U. 2001. Effects ofearly feed restriction on growth, fat accumulation and meat composition in unsexed broiler chickens. Asian-Aust. J. Anim

Scott, M.L.M.C. Nesheim and R.J. Young. 1982. Nutrition of the Chickens. Second Ed. M.L.Scott and Associates, Ithaca, New
York.

Shapira, F. and I. Nir. 1995. Stunting syndrome in broilers : Effect of age and exogenous amylase and protease on performance, development of the digestive tract, digestive enzyme activity, and apparent digestibility. Poult. Sci. 74: 2019 2028.

Siregar, A. D., M. Sabrani, dan S. Pramu. 1982. Teknik Beternak Ayam Pedaging di Indonesia, Mergie Group. Jakarta.

Soeparno. 2015. Ilmu dan Teknologi Daging. Cetakan ke-6 (edisi revisi). Gadjah Mada. University Press. Yogyakarta.

Steel, R. G. D. dan J. H. Torrie. 1991. Prinsip dan Prosedur Statistika. Diterjemahkan oleh Bambang Sumantri. PT. Gramedia Pustaka Utama. Jakarta.

Suartiningsih, N. P. M., G. A. M. K. Dewi, I. M. Nuriyasa, dan I. M. Wijana. 2017. Produksi karkas ayam kampung yang diberi kulit buah naga (Hylocerus polyhizus) terfementasi. Panduan dan Kumpulan Abstrak Seminar Nasional. Jambi.

Thalele. Y., Martin. E. R. M, Fredy. J. N dan Cherlie. L. K. S. 2018. Pengaruh penambahan ramuan herbal pada air minum terhadap persentase karkas, persentase lemak abdomen dan persentase hati pada ayam kampung super. Jurnal Zootek. Vol. 38 No. $1: 160-168$.

Wahidayatun. 1983. Kajian tingkat kenyamanan itik yang dipelihara secaragembala dan terkurung. Laporan Hasil Penelitian.Fakultas Peternakan. Universitas Jendral Soedirman. Purwokerto.

Wahju. 1992. Ilmu Makanan Ternak. Jogjakarta: Universitas Gajah Mada Press.

Waskito, D. M. W. 1981. Pengaruh berbagai faktor lingkungan terhadap gala tumbuhan ayam-ayam broiler. Disertasi. Universitas Padjajaran, Bandung. 
Widyakarya Nasional Pangan dan Gizi [WNPG]. 2012. Prinsip dasar Ilmu Gizi. Jakarta. PT Gramedia Pustama Utama.

Williamson, G. dan W. J. A. Payne. 1978. An Introduction to Animal Husbandry in The Tropics, Second Edition, ELBS and Longman Group Limited, London. Yao, Y., Xiaoyan, T, X. Haibo, K. Jincheng, $X$. Ming, and W. Xiaobing. 2006. Effect of choice feeding on performancegastrointestinal development and feed utilization of broilers. Asian-Aust. J. Anim. Sci. 19:91-96. 